\title{
Towards the Application of Inquiry Learning Approach in Classroom: Students Exploration of Changes in Understanding Meaningful Mathematical Concepts
}

\author{
Filzah Nazirah, Nuraina*, Herizal, \& Mursalin \\ Department of Mathematics Education, Universitas Malikussaleh, Aceh Utara, Indonesia \\ filzahnazirah19@gmail.com; nuraina@unimal.ac.id; herizal.mathedu@unimal.ac.id; mursalin@unimal.ac.id \\ *Corresponding Author: nuraina@unimal.ac.id
}

\begin{abstract}
This study was intended to investigate the influence of inquiry learning approach assisted with square word media toward students' mathematical understanding ability in learning mathematics. This study was conducted through quantitative research procedures namely quasi-experimental design. The populations were all students of class $X$ at MAS Syamsuddhuha. The samples were 25 students of class X MIA 1 and 25 students of class X MIA 2, selected by purposive sampling. The nonequivalent posttest-only control group design was used. The data were obtained from the post-test results of the students' mathematical understanding; they were analyzed by using SPSS 18 software. Since the data was not normal, the non-parametric Mann-Whitney test was applied. The findings of this study showed that the significant value of the test was 0,000 and it was less than 0.05 allowed the $\mathrm{H}_{0}$ rejected. It can be concluded that there was an influence of inquiry learning approach assisted by word square media on students' mathematical understanding ability, which was done in the study of trigonometry II for class X at MAS Syamsuddhuha. Hence, mathematical understanding ability is a crucial aspect in solving mathematical problems which can be measured by applying inquiry learning approach in classroom.
\end{abstract}

Keywords: mathematical understanding; inquiry learning approach; trigonometry; word square;

\section{Introduction}

The goal of education in Indonesia is stated in the nation objectives for education. It stands in contrast with national development goal in that it designs to establish a well mannered civilian. The goals per se are eventually derived from and set by Pancasila and the 1945 Constitution. Thus, teachers are thought of a crucial aspect in formal education in a way that they are responsible for increasing and extending the quality of education system. According to The law No. 20, 2003 which pertains to the national education system, the term education is defined as a conscious and planned effort to create the learning process so that students can actively develop their spiritual strength, self-control, intelligence, righteous deed, personality, and skills hopefully contribute to their society and nation. In short, despite the attempts which have been taken to improve the learning process lies a significance issue, the fact that the very low quality of learning and the insufficient motivational input to develop students' thinking are one of the obstacles faced in the educational sector which resulted in students learning outcome (Sanjaya, 2016).

Mathematics is regarded as the mother of science which has its own profound meaning, having its learners gain and extend their logical, critical, and creative thinking. Undeniably speaking, in both of every branch of knowledge and even in daily activity, the involvement of mathematics resists hardly to get perished (Ulandari, Putri, Ningsih \& Putra, 2019). Furthermore, learning mathematics can accelerate its leaner to be able to have a rational thinking. This advantage can be reaped due to the fact that mathematics has a strong and obvious relationship from one concept to another. Hence, based on the results of the observation and interview conducted toward mathematics teachers at MAS (Private Islamic Senior High School) Syamsudduha revealed so considerable a constraint that students still undergo ineffective and monotonous learning model, which caused them to have less motivation to learn. In addition, students were hardly able to develop their learning as they dealt with the inappropriate learning process either in classroom or in boarding school. As such, most of students regarding to their mathematical understanding indicated that they were unable to digest and apply the formula in order to calculate, remember and solve 
the mathematical task appropriately. In fact, most of them also found to have been unable to understand the multifaceted mathematical concepts.

Several previous studies, such as Pur Wanita et al (2019); Pohan (2019); Lukitasari (2020); Jehadan et al (2020); Anggraini et al (2020); and Sahronih et al (2020) stated that the inquiry learning model gave satisfactory results on student learning outcomes. In line with Ningsih et al (2019) the results of their development research also gave good results on student achievement. Not only that, another similar study was also conducted by Vajoczki et al (2011) that the inquiry learning model, discipline and class size also determine success and comfort in learning. A type of inquiry model, other learning models belonging to the cooperative model also provide effective learning outcomes (Irfanto et al, 2019). In addition, according to Dewi (2019), one other method that is able to provide ease of learning is the Mind Map, because it provides a concept mind map for students to understand. Wahyuni et al (2020); and Widiantoro et al (2020) comparing learning outcomes with the direct learning model showed significant results, the Problem-Based Learning model also had a positive influence on student learning outcomes.

Another study was also conducted by Jayanto et al (2019) that the guided learning model developed was able to improve students' thinking skills. In line with Putriani \& Rahayu (2018) that the discovery model improves student learning outcomes on circular material. In line with Ernest (2019); Nufus \& Mursalin (2020); Dahliana et al (2019) that improving students' abilities, such as creative and critical thinking, really depends on the learning model used by the teacher. Yarmasi et al (2020); Paroqi et al (2020); Maulidawati et al (2020); and Marhami et al (2020) in their research stated that learning outcomes can only be achieved if the learning atmosphere managed by the teacher is good, so student learning outcomes are good.

In accordance with the result of the interview with one of the mathematics teachers at MAS Syamsuddhuha, it was also found that the Kriteria Ketuntasan Minimal (Minimum Completeness Criteria) of the mathematics lesson was 83. This grade was insufficient to the repetition test on daily basis at class $X$ at the institution. Precisely, the minimum completeness criteria obtained by students was regarded inadequate to pass the Trigonometry II lesson. The inconvenient grade as such occurred was due to the fact that most students were unable to understand the trigonometric functions, sine and cosine, were applied to figure out the width of triangle. Therefore, students failed in understanding the application of the mathematical formula affecting their grade of the daily repetition test. Having done the overviewed with the mathematics teacher at the school, we researchers encountered that the core of the problem coped by students in learning mathematics was on the use of media and learning approach, considered inappropriate to be exerted in their classroom.

In learning mathematics, students'understanding ability is of paramount importance. This ability influences their attainment in learning mathematics at their early stage. The students who are unable to grasp the appropriate mathematical concept; they tend to make mistakes in solving their mathematics tasks (Herizal, Suhendra \& Nurlaelah, 2019). Thus, students' mathematical understanding acts as a strong basis in thinking and accomplishing the mathematical problem for either inside or outside classroom.

The importance of having an ability of mathematical understanding is also discussed by Satrock that the concept is a key aspect in learning process (Hendriana, Rohaeti \& Sunamo, 2017). Likewise, the ability works as a strong foundation for students in thinking to do and finish the mathematics problem in classroom or in real life. It is also considered as a core part of learning mathematics at high school. With this learning concept, students are able to make and draw the conclusion. Taking the mathematical understanding ability into account, students are demanded to learn on their own, developing their understanding in accomplishing their tasks. This narration shows that the inquiry learning model requires students to learn independently. Other view it as a process in which students are required to learn by asking and researching on their own. Also they are asked to learn through identifying, searching, discovering and investigating the problem (Tjiptiany, As'ari \& Muksar, 2016). In accordance with the above views, we assume that by applying the inquiry learning approach, students can come across the concept resembling a real-world problem. It is indicated that students who undergo the learning model in their classroom are superior to those that receive the learning conventionally; students are well-oriented and heightened in their learning process (Purwasih, 2015).

Apart from using the inquiry learning approach, we also applied a learning media to equate students' perception and understanding easier. The media is thought of as means of conveying the learning message and information from teacher to students in classroom. Therefore, we applied the word square which was used in students' activity form, a random concept learnt by students helping them to do their tasks. Accordingly, it was found so helpful that students gave a positive response, $93 \%$, on using word square media in their activity form, data gained from questionnaires involving 20 students (Andini, 2018). Based on the above issues, we have attempted to perform a research entitled "Towards the Application of Inquiry Learning Approach in Classroom: Students Exploration of Changes in Understanding Meaningful Mathematical Concepts." 


\section{Methods}

The study is designed based on quantitative research approach, the quasi experimental research. It is recognized as an investigation relying on the philosophy of positivism conducted to certain cluster of population and sample (Sugiyono, 2016). In investigating the influence of the inquiry learning approach, which was assisted with word square media toward the ability of students' mathematical understanding, this research was performed based upon the non-equivalent posttest-only control group design. The differences between quasi experimental and non-equivalent posttest-only control group design as mentioned above is situated at how the sample of the research is obtained. The non-equivalent posttest only control group considers the non-random sample technique for both its experimental and control group (Lestari \& Yudhanegara, 2015) as the Table 1.

Table 1. Research Design

\begin{tabular}{cc}
\hline $\mathrm{X}$ & $\mathrm{O}_{1}$ \\
---- & --- \\
& $\mathrm{O}_{2}$ \\
\hline
\end{tabular}

Explanation:

Source: Lestari and Yudhanegara (2015:136).

$\mathrm{X}=$ Treatment (Inquiry learning approach assisted word square media)

$\mathrm{O}_{1}=$ Post-test of Experiment class

$\mathrm{O}_{2}=$ Post-test of control class

This study was done at MAS Syamsuddhuha, located in Cot Murong, Dewantara, Aceh Utara Regency, Aceh Province. It was performed on the second semester of academic of 2020. The population were all students registered in class X MIA consisting of five classes; Class X MIA 1, XMIA 2, X MIA 3, XMIA 4, and $X$ IIS. The purposive sampling procedure was used in selecting the number of students involved in this study. This procedure was chosen for the fact that the sample has been categorized to have certain criteria allowing answering the research problem. The students who took part in this study has been assessed to possess relatively the same level of understanding ability as one to another comparing with the other classes, as reported by mathematics teacher at the school. For that reason, the class X MIA 1 was selected as the experimental group undergoing the treatment of inquiry learning approach assisted square word media. Meanwhile, the control group selected in this study was the class X MIA 2, going through scientific teaching approach without assisting with any media. The type of the investigation undertaking as means to look into and figure out the students' mathematical understanding ability was a written test; the type of the test allowing students to do the answer in detail and think with higher precision. It consisted of four items which can be evaluated effectively.

Examining the ability of students' mathematical understanding, the description test was also applied constructed on the following indicators:

1. The mechanical understanding which allows students to remember and apply the formula with a simple calculation.

2. The drawing example which gives students the opposite pattern from the learning concept used.

3. The rational, functional and relational understanding requires students to identify the relationship between the concepts and perform the calculation together with mathematical explanations.

4. The rational understanding; proving the formula.

The type of the test given to students has been evaluated by mathematics lectures prior to the test was given. This was done to see its validity, degree of differences and difficulty. Having done the post-test, the results were analyzed through Mann-Whitney test, a non parametric statistical procedure as the data were distributed abnormally.

\section{Results and Discussions}

\subsection{Results}

As it has been outlined in the previous sections, this study was intended to explore the influence of teaching students the inquiry learning approach integrated with the word square media toward their mathematical understanding ability. At the same time, the students of the control group were treated with the teaching scientific approach and they were not equipped with any media. The result of the test indicated a significant point on the ability on students' mathematical understanding, having performed the teaching to both experimental and control group. The test was given to a number of 50 students; they were 25 students of experimental class and the other 25 were from the control group. The finding gathered from the post-test was analyzed comprehensively and it can be seen from the following table 2. 
Table 2. Statistical Description of Students' Mathematical Ability

\begin{tabular}{cccccc}
\hline \multirow{2}{*}{ Score } & \multicolumn{5}{c}{ Experimental Class } \\
\cline { 2 - 6 } & $\mathrm{N}$ & $X_{\text {min }}$ & $X_{\text {maks }}$ & $\bar{x}$ & $\mathrm{~S}$ \\
\hline Post-test & 25 & 6 & 13 & 8,44 & $\mathrm{~S}$ \\
\hline & $\mathrm{N}$ & $X_{\text {min }}$ & $X_{\text {maks }}$ & $\bar{x}$ & 1,15 \\
\hline Post-test & 25 & 1 & 7 & 5,92 & \\
\hline
\end{tabular}

Table 2 indicates that the minimum score of post-test conveying students' mathematical understanding ability from the experimental class is 6 while the score from the control group is 1 . In addition, the maximum score of the experimental class is 13 and of the control group is 7 . The average score of the post-test taken from both experimental and control class are 8.44 and 5.92 respectively. This score can be noted from the teaching used in both of the classes, the experimental and control class. The former was introduced with the inquiry learning approach and word square media while the latter was given the scientific approach without assisting with any media. It showed that the score from experimental class was far better than that of the control and it be seen from the figure 1.

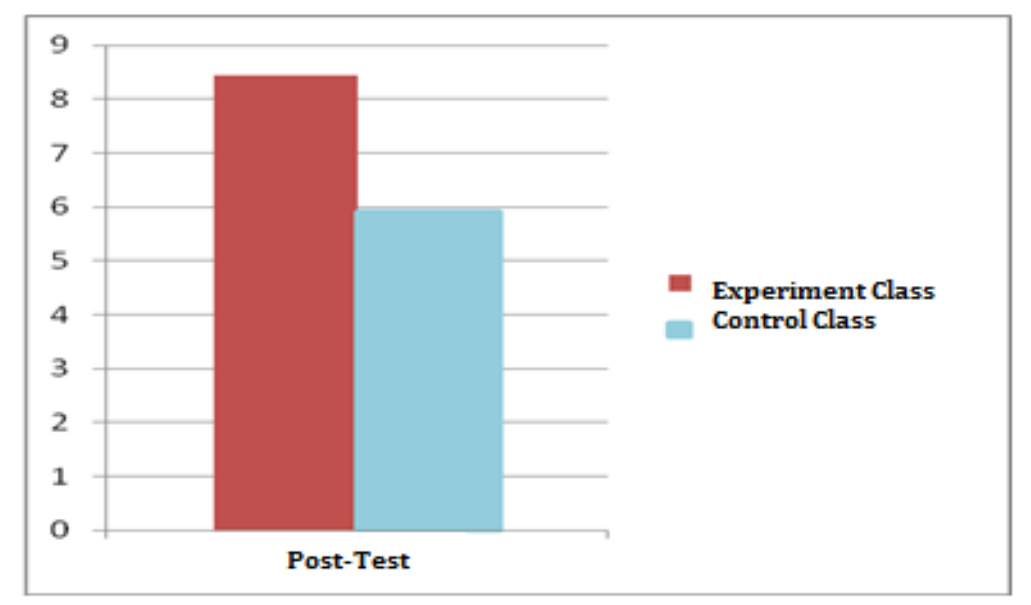

Figure 1. Average Score of Post-test

The figure 1 shows that the average score of post-test underlying students' mathematical understanding ability from the experimental class (8.44) was higher than that of control class (5.92). The standard deviation taken from the post-test of experimental class depicting mathematical understanding ability (2.21) was lower than that was resulted from the post-test of the control group (1.15). To observe the significant influence of the teaching approach given to both of the groups in the study of trigonometry II for class $\mathrm{X}$ of MAS Syamsuddhuha, the hypothesis test procedure was conducted. The test as such was done through the inferential statistic, t-test, toward the score of post-test from both of the classes. The prerequisite test was also done prior to the application of T-test, namely the normality and homogeneity test. The normality test used in this study was Shapiro-Wilk test. The statistical results can be seen from the table 3.

Table 3. Results of Normality Test

\begin{tabular}{lccc}
\hline & \multicolumn{3}{c}{ Shapiro-Wilk } \\
\cline { 2 - 4 } & Stat. & df & Sig. \\
\hline Experimental Class & .789 & 25 & .000 \\
\hline Control Class & .549 & 25 & .000 \\
\hline
\end{tabular}

It can be seen from the table 3 above that the significant score of the Shapiro-Wilk normality test is 0.000 which originated from experimental class while 0.000 from the control class. Referring to the conditions of hypothesis, $\mathrm{H} 0$ is accepted if the significant score is more than $0.005(>0.005)$. Hence, it can be concluded that the post-test score of students' mathematical understanding ability is not distributed normally. Since the data analysis from the score of the prerequisite test showing the normality test was not fulfilled, the analysis of the data using the T-test could not be proceeded unless with the application of another parametric test, Mann-Whitney. The analysis of the data is done based on the following hypotheses: 
$H_{0}: \eta_{1}=\eta_{2}$ : There is no significant influence of the inquiry learning approach assisted word square media toward the abilty of students' mathematical understanding in learning Trigonometry II for class $X$ at MAS Syamsuddhuha.

$H_{a}: \eta_{1} \neq \eta_{2}$ : There is significant influence of the inquiry learning approach assisted word square media toward the abilty of students' mathematical understanding in in learning Trigonometry II for class $X$ at MAS Syamsuddhuha.

The data resulted from the tests were analyzed by using the statistical software, SPSS 18 . The result summary of the non-paramtric test can be seen at the table 4 .

Table 4. The Result of Mann-Whitney Test

\begin{tabular}{lc}
\hline & Score \\
\hline Mann-Whitney U & 57.000 \\
\hline Wilcoxon W & 382.000 \\
\hline$Z$ & -5.210 \\
\hline Asymp. Sig. (2-tailed) & .000 \\
\hline
\end{tabular}

Based on the data of the above table 4, the result of the Mann-Whitney Test on the data of students' mathematical understanding ability is obtained as much as 0.000 . According to the criteria of the test, the H0 is rejected if the value is $<0.005$ at column sig. The significant finding of statistic test is identifed as much as 0.000 , smaller than 0.005. This result shows that the H0 is rejected and the Ha is accepted. It can be concluded that using inquiry learning approach assisted with word square media has a significant influence toward students' mathematical understanding ability in learning Trigonometry II for class X at MAS Syamsuddhuha since the data analysis are emanated from the Mann-Whitney Non-Parametric Test.

\subsection{Discussion}

This study was conducted to investigate the influence of inquiry learning approach assisted with word square media toward the abilty of students in mathematical understanding, particulary in learning Trigonometry II for class X at MAS Syamsuddhuha. The significant influence of the treatment was analyzed from the result of the post-test, obtaining from both of experimental and control class. The score of the posttest from the experimental class undertaking the inquiry learning approach and word square media was 8.44 meanwhile with those of control class was 5.92. Therefore, it can be concluded that the post test score from experimental class was significantly higher than that of control group learning trigonemetry II with scientific learning approach without any used of media. This proved that students' ability in understanding mathematical concept through inquiry learning approach assisted word square media was better than those of undertaking scientific approach in learning the trigonometry II.

The findings of this study is synonmous with a previous research which states that the improvement of students' mathematical understanding ability undergoing inquiry learning approach and media word square is guided efectively than on learning with the conventional teaching (Tjiptiani, As'ari \& Muksar, 2016). It also reflects a study done by Purwasih (2015) that the application of word square media reaches the result of material validation as much as $76 \%$. The result of media validation itself was at average percentage of $95 \%$, being at appropriate criteria to be used (Purwasih, 2015). The result of Mann-Whitney test analyzing students' ability in mathematical understanding was identified 0.000 . As the criteria says, if the value at cloumn sig. is $<0.005, \mathrm{H} 0$ is rejected. The value of the statistical test in this study was found 0.000 and it was smaller than 0.005. It is therefore, the H0 is rejected while the Ha is accepted. It can be noted that there was a significant influence of the inquiry learning approach toward students' ability in their mathematical understanding particulary in learning Trigonometry II.

This study was conducted in four consequitive meetings, the first three of which was the learning of trigonometry II and it was done through the inquiry learning approach with word square media. The teaching process was implemented in accordance with a set of teaching and learning materials, which had been already prepared. On the fourth meeting, students were given the post-test, aiming at coming accross the influence of scientific teaching approach on students' mathematical understanding ability. The mathematical description test was given, which comprised of 8 questions that it had been previously validated. As such, we selected a number of 4 questions used in testing format because it was appropriate to the indicators of mathematical understading concept. In this research, we directly practiced and carried out the application of the enquriy learning approach assisted with word square media toward students' mathematical understanding. In general, the implementation of all of the learning components of the inquirylearning approach and media word square was effective. The same procedure was also succesfully conducted to the control group, notwithstanding with the use of the inquiry learning procedure and the word square media. 


\section{Conclusion}

The mathematical understanding is a basic ability in solving problem or questions pertain to the learning of mathematics as it is asscociated with students' mathematical concept. Consequently, this ability must be trained to students. One of the approaches that can be applied in teaching mathematic is the inquiry learning model which can assisted with word square media. This approach marked a significant influence toward the ability of students' mathematical understanding as they are required to find the concept on their own through a series of acitivities reflecting the real world use. Also, students found it meaningful and easy to remember the taught mathematical concepts.

\section{Acknowledgement}

The authors would like to thanks to the people who have been instrumental in their assistance and the successful completion of this study.

\section{Author's Contribution}

All authors discussed the result and contributed to from the start to final manuscript.

\section{Conflict of Interest}

The authors declare that they have no competing interests.

\section{References}

Andini, M. (2018). Pengembangan Media Pembelajaran Word Square pada Materi Konsep dan Kebijakan Perdagangan Internasional Kelas XI IIS Di SMA Negeri 1 Bangsal, Jurnal Pendidikan Ekonomi (JUPE), 6(3), 242-248.

Anggraini, N. D., Astra, I. M., \& Utomo, E. (2020). The Effect of Inquiry Learning Model And Scientific Literacy Toward Students' Critical Thinking Skills In Primary School. International Journal for Educational and Vocational Studies, 2(3).

Dahliana, D., Marhami, M., \& Mursalin, M. (2019). Improving Students' Mathematical Critical Thinking Abilities Through the Problem Solving Method on the Sequences and Series Course. International Journal for Educational and Vocational Studies, 1(7), 813-816.

Dewi, A. K. (2019). Improving students learning outcomes through mind map in human reproductive system topic in natural science learning. International Journal for Educational and Vocational Studies, 1(7), 702-706.

Ernest, P. (2019). A Theoretical Inquiry into the Ethics of Mathematics Teaching. Malikussaleh Journal of Mathematics Learning (MJML), 2(2), 68-75.

Hendriana, H., Rohaeti, E. E., \& Sumarmo, U. (2017). Hard Skill dan Soft Skill Matematik Siswa. Bandung: Refika Meditama.

Herizal, H., Suhendra, S., \& Nurlaelah, E. (2019). The ability of senior high school students in comprehending mathematical proofs. Journal of Physics: Conference Series, 1157(2), 1-6.

Irfanto, W. Y., Mustaji, M., \& Jacky, M. (2019). The Effect of Cooperative Learning Model Type Two Stay Two Stray and Learning Style on Social Sciences Learning Outcomes of Grade IV Elementary School Students. International Journal for Educational and Vocational Studies, 1(3), 212-216.

Jayanto, I. F., Noer, S. H., \& Caswita, C. (2019). Development of Guided Discovery Learning to Improve Reflective Thinking. International Journal of Trends in Mathematics Education Research, 2(2), 106-111.

Jehadan, H., Nur, M., \& Supardi, Z. I. (2020). The Development of Physics Guided Inquiry Learning Package To Facilitate The Science Process Skills of Senior High School. International Journal for Educational and Vocational Studies, 2(10).

Lestari, K. E., \& Yudhanegara, M. R. (2015). Penelitian Pendidikan Matematika. Bandung: Refika Aditama.

Lukitasari, F., Nurlaela, L., Ismawati, R., \& Rijanto, T. (2020). Comparison of Learning Outcomes Between Discovery Learning with Inquiry Learning Reviewed of Student Learning Independence At Vocational High School. International Journal for Educational and Vocational Studies, 2(10).

Marhami, M., Fonna, M., Mursalin, M., \& Nuraina, N. (2020). The Effect of Video Conference Assisted Online Learning on Students' Mathematical Problem Solving Ability during the Covid-19 Pandemic. International Journal for Educational and Vocational Studies, 2(11).

Maulidawati, M., Muhammad, I., Rohantizani, R., \& Mursalin, M. (2020). The Implementation of Make A Match Type Cooperative Learning Model to Improve the Mathematical Connection Ability. International Journal for Educational and Vocational Studies, 2(11). 
Ningsih, W. K., Riyanto, Y., \& Suyanto, T. (2019). The development of pop up 3d general map using discovery learning models to improve creativity and learning outcomes of social studies grade $\mathrm{V}$ elementary school. International Journal for Educational and Vocational Studies, 1(2), 86-91.

Nufus, H., \& Mursalin, M. (2020). Improving Students' Problem Solving Ability and Mathematical Communication through the Application of Problem Based Learning. Electronic Journal of Education, Social Economics and Technology, $1(1), 43-48$.

Paroqi, L. L., Mursalin, M., \& Marhami, M. (2020). The Implementation of Realistic Mathematics Education Approach to Improve Students' Mathematical Communication Ability in Statistics Course. International Journal for Educational and Vocational Studies, 2(10).

Pohan, J. E. (2019). The Development of Inquiry Learning Model on Indonesian Language Lessons. International Journal for Educational and Vocational Studies, 1(4), 335-338.

Putriani, D., \& Rahayu, C. (2018). The effect of discovery learning model using sunflowers in circles on mathematics learning outcomes. International Journal of Trends in Mathematics Education Research, 1(1), 22-25.

Purwasih, R. (2015). Peningkatan Kemampuan Pemahaman Matematis Dan Self Confidence Siswa MTs Di Kota Cimahi Melalui Model Pembelajaran Inkuiri Terbimbing. Jurnal Ilmiah STKIP Siliwangi Bandung, 9(1), 16-25.

Purwanita, Y., Riyanto, Y., \& Suyanto, T. (2019). The Influence of Multimedia Assisted Inquiry Learning Methods on My Heroes' Theme of Critical Thinking Skills and Learning Outcomes of Class IV Students of Elementary School. International Journal for Educational and Vocational Studies, 1(2), 75-80.

Sanjaya, W. (2016) Strategi Pembelajaran. Jakarta: Kencana.

Sahronih, S., Purwanto, A., \& Sumantri, M. (2020). The effect of use interactive learning media environment-based and learning motivation on science learning outcomes. International Journal for Educational and Vocational Studies (IJEVS), 2(3).

Sugiyono. (2016). Metode Penelitian Kombinasi (Mixed Methods). Bandung: Alfabeta.

Tjiptiany, E., As'ari, A, \& Muksar, M. (2016). Pengembangan Modul Pembelajaran Matematika Dengan Pendekatan Inkuiri Untuk Membantu Siswa SMA Kelas X Dalam Memahami Materi Peluang. Jurnal Pendidikan: Teori, Penelitian, dan Pengembangan, 1(10), 1938-1942.

Ulandari, N., Putri, P., Ningsih, F., \& Putra, A. (2019). Efektivitas Model Pembelajaran Inquiry terhadap Kemampuan Berpikir Kreatif Siswa pada Materi Teorema Pythagoras. Jurnal Cendekia : Jurnal Pendidikan Matematika, 3(2), 2272377.

Vajoczki, S., Watt, S., Vine, M. M., \& Liao, X. (2011). Inquiry Learning: Level, Discipline, Class Size, What Matters?. International Journal for the Scholarship of Teaching and Learning, 5(1), n1.

Wahyuni, D., Samani, M., Wiyanto, T., \& Rijanto, T. (2020). Influences of Problem-Based Learning Models on Class XI Students Learning Outcomes in Subject of Light Vehicle Engine Maintenance at KAL-1 Vocational School Surabaya. International Journal for Educational and Vocational Studies, 2(5).

Widiantoro, O., Kusnan, K., Suparji, S., \& Rijanto, T. (2020). Differences in Learning Outcomes Using Direct Learning Models Viewed from Spatial Ability: Study At Basic Survey Working Lesson in the Engineering Surveying. International Journal for Educational and Vocational Studies, 2(4).

Yarmasi, Y., Fonna, M., \& Mursalin, M. (2020). The Influence of Cooperative Learning Model Type Team Assisted Individualized of Interactive Media Assistance to Students' Mathematical Communication Ability. International Journal for Educational and Vocational Studies, 2(9). 